\title{
掛流し米に関する研究
}

\author{
（第 4 報）ビタミンの流出
}

奥 義信, 石上藤太, 吉村宏一, 野白暿久蜼*

(昭和 37 年 6 月 15 日受理)

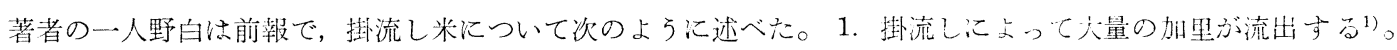

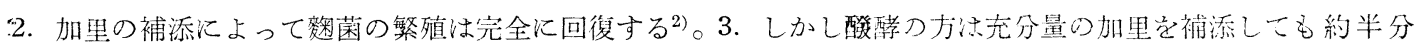
しか回復しない3。

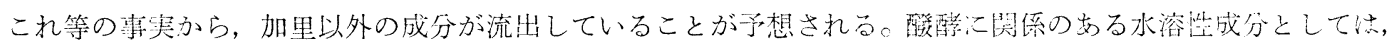
水溶性ビタミンが考えられるので，特汇酵母の增殖に大きな影響を持つと言われていかパントテン酸，ビオチン， イノシトールについて, 流出の程度を調べた。尚, サイアミシ隹, 洗米挑完全こ流出することがわかっている ので), これについて恰討を行わなかった。

\section{実験 方 法}

1. パントテン酸（P.A.）定量は Lactobxcillus arabinosus ATCC 8014 它使用する bioassayによった5)

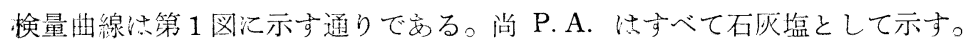
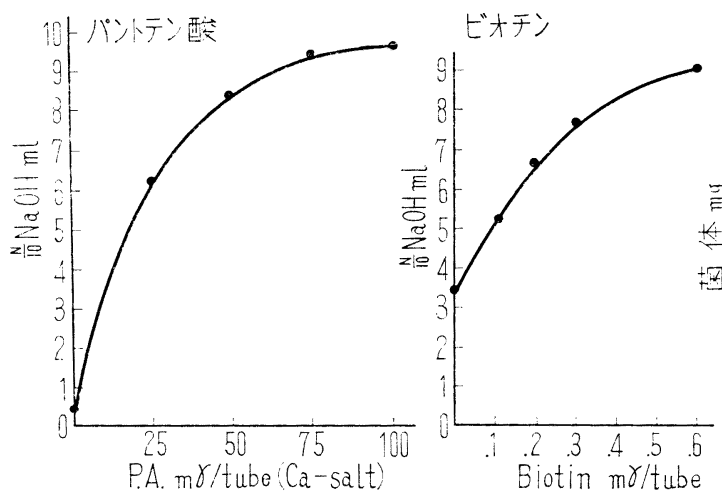

イハトール

第1図ビタミン 検量曲線

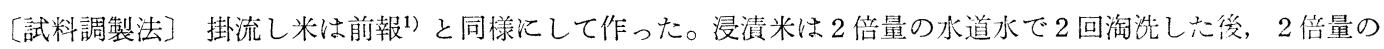
水道水に室温 $\left(15 \sim 20^{\circ} \mathrm{C}\right) 8$ 時間浸漬した後風乾して貯光た。結合型 P. A . を free にするにはタカジアスター ゼを用いた。タカジアの抽出作用は不完全であって, 腸フォスファターゼと肝醅素を用いるのが良いと報告され ている ${ }^{6}$ が，実際の酒造条件に一致させるためタカジアを使用した。消化は次の通り汇行なった。粉厒白米 $10 \mathrm{~g}$, 水 $10 \mathrm{~m} l$ を $200 \mathrm{ml}$ 三角フラスコに入れ, コッホ鉒で一時間蒸す。これにタカジア原末 $1 \mathrm{~g}$ (白米汇対して 10 $\%$ ), 水 $200 \mathrm{ml}$ を加光, $300 \mathrm{~m} l$ の三角フラスコに移して, $37^{\circ} \mathrm{C}, 48$ 時間消化する。後 $100^{\circ} \mathrm{C}, 30$ 分の加熱処 理を行ない, 濾過して $2 \sim 5$ 倍にうすめて試料とする。

2.ビオチン (Bi) P.A. と同様，Lactob.arabi.ATCC 8014 を使用する bicassay によった た娭量曲線は 第 1 図に示す。

〔試料調製法〕はじめ P. A. と全く同じ方法によったが，掛流し米では blank（タカジアのみ）の方が却って

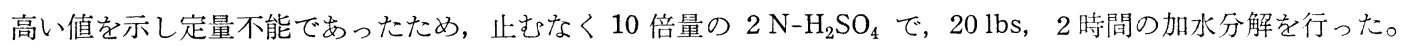

\section{*国税庁醇造試験所}


福井等も P.A. の定量に際してかかる high blank を認めている6)。

3. イノシトール (In) 定量には普通 Sacch. carlsbergensis 4228 を用いる bioassay が用いられているの で, これを先ず武みた。しかし白米中の In 量が予想外に少なく, 塩酸分解液を原液の盡使用すると, 比濁によ る酵母增殖度の測定が不可能でめる。これについては Calhoun 等も, 小麦及び小麦製品のビタミン含量の測定 に際して, Sacch. carlsb. 法がこれ等の試料のIn 定量には適しないことを述べ, Neurospora crassa 37401 (ATCC 9683) を用いる bioassay を推奖している7)。著者等む後の方法によった ${ }^{8) 99}$ 。検量曲線は第 1 図に示す 通りである。

[試料調製法] 粉粋白米 $10 \mathrm{~g} に 18 \% \mathrm{HCl}, 100 \mathrm{ml}$ を加え, 逆流冷却器を附して 6 時間加熱する。これを減 圧濃縮して $\mathrm{HCl}$ を充分に除去した後, pH 6.8 に調節し, 蒸溜水で $100 \mathrm{ml}$ に充たす。

\begin{tabular}{|c|c|c|c|c|c|c|c|c|}
\hline 第 1 表 & \multicolumn{2}{|c|}{ パントテン酸含量 } & 第 2 表 & \multicolumn{2}{|c|}{ ビオチン含量 } & \multicolumn{3}{|c|}{ イノシトール含量 } \\
\hline 米 & P.A. $\gamma / \mathrm{g}$ & 流出率\% & 米 & $\mathrm{Bi} \mathrm{m} r / \mathrm{g}$ & 流出率\% & 米 & In $\gamma / g$ & 流出率\% \\
\hline j $80 \%$ 白米 & 5.00 & & $75 \%$ 白米 ( I ) & 19.5 & & $75 \%$ 白 & 88 & \\
\hline $24 \mathrm{~h}$ 掛流乙米 & 0.84 & 83 & $\{8 \mathrm{~h}$ 浸漬米 & 13.6 & 30 & & & \\
\hline (75\% 白米 & 2.07 & & $24 \mathrm{~h}$ 掛流し米 & 9.9 & 49 & $24 \mathrm{~h}$ 掛流し米 & 77 & 13 \\
\hline$\{8 \mathrm{~h}$ 漫漬米 & 0.86 & 59 & (75\%白米 (II) & 19.4 & & & & \\
\hline (24h 掛流し米 & 0.29 & 86 & $\{8 \mathrm{~h}$ 浸漬米 & 14.3 & 26 & & & \\
\hline & & & $24 \mathrm{~h}$ 掛流し米 & 13.0 & 33 & & & \\
\hline
\end{tabular}

\section{結 果 及 び 考 察}

P.A. 量を第 1 表, Bi 量を第 2 表, In 量を第 3 表に示す。

清酒酵母の必須因子である P.A. 心浸漬で 60\%，掛流しで 80〜90\% とかなりの量が流出して抢り，この両 操作が本質的に注同じ操作であること光がこれによっても裏書きされている。小平等は，P.A. 欠乏時に酵母が $\mathrm{H}_{2} \mathrm{~S}$ を生産すると報告した ${ }^{10)}$ が，著者等も掛流し米もろみに $\mathrm{H}_{2} \mathrm{~S}$ 臭の強いことを認めた。米の P. A. 量が浸漬 また快蒸しによって減少することは中村等も述べて拈り ${ }^{11)}$ ，また福井等の報告4)からも推知することが出来る。

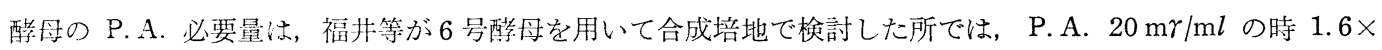
$10^{7} / \mathrm{m} l$ の最大值になることが報告されている(12)。清酒もろみでもこの通りとすれば, 酵母密度 $2.5 \times 10^{8} / \mathrm{m} l$ と

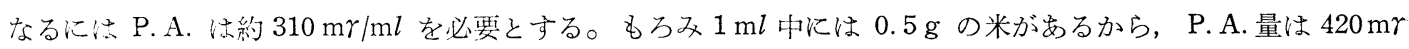
となり，必要量を上回ることになる。但し，合成培地の酵母心一般にもろみ酵母より形が小さいので，この計算

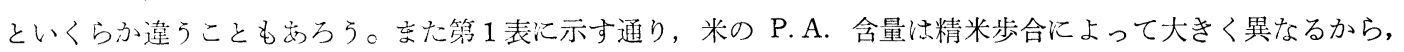
精米歩合の高い米では掛流しを行っても P.A. 欠乏にならない場合もある。

本実験で淰白米の消化に濃厚タカジアを用いたので, 実際のもろみでも結合型 P.A. が常にこの実験と同様 に遊離するか否かは疑問であり，モデル実験に近い条件，即ち $0.1 \%$ タカジア， $30^{\circ} \mathrm{C}$ の消化条件では，P.A. 含量愉 2 図に示す通りはるかに低い值を示す。但し時間とともに少しつつ增加し，また実際のもろみでは，P. A. の豊富な啭13)が加わるので, P.A. はかなりの程度迄 充足されるものと考光られる。

ビオチンは掛流しでも 30〜50\% の流出で割に少ない から清酒酵母の增殖に対して促進的な役割を有していて も，掛流しで永り問題にならないと思われる。

イノシトールの流出率は 24 時間掛流しの場合でも僅 か $13 \%$ 程度で, P.A., Bi にくらべはるかに少ない。

注目すべきことは，白米の In 含量がこれ迄の報告に くらべて著しく低いことである。福井等は S. carlsb. 法 を用いて, 白米中の In 量を364 850 r/g と報告してい $る^{6)}$ 。この差異が定量法によるものか, 白米のちがいに よるものか明らかでないが, 後者について森等は次の様

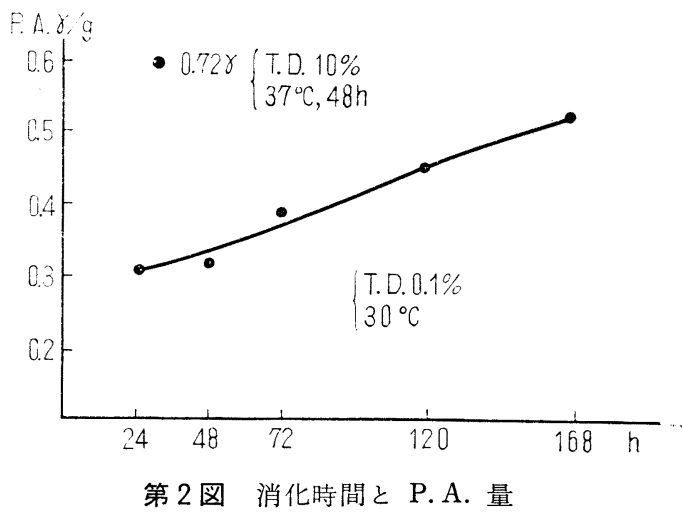


そ報告している。

In はとの燐酸エステルであるフィチンとして白米中に存在しているが，こ机怡酸溶性燐として定量される。 森等ははじめ白米中のフィチン態橉を $20 \sim 45 \mathrm{mg}$ P/100 g 米と報告し, これ《福井等の In 含量と一致すると述

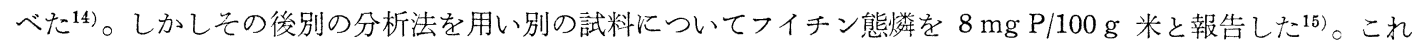
は著者の In 含量に一致するものである。

7 号酵母の增殖に必要な In 量は福井等によると $5 \sim 10 \mathrm{r} / \mathrm{m} l$ で, 前述の P.A. と同じ様に計算すると, 清酒 もろみで注 $75 \sim 150 \mathrm{r} / \mathrm{m} l$ 必要となる。 $80 \mathrm{r} / \mathrm{g}$ 白米ならこの必要量の $1 / 2 \sim 1 / 4$ となり, 清酒もろ久での In, フ ィチンの有効性が理解出来る。

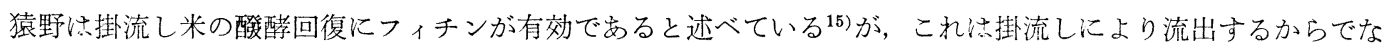
く、もとると白米中に In が不足しているからであらう。著者の一人野白がフィチンが無効であるとした の注， フィターゼの少ないタカジア17)を咊の代りに使用したためである。

試験菌を分譲された応用微生物研究所 飯塚 広助教授, 醱酵研究所 (IFO) 長谷川武治所長に深謝致します。

$$
\text { 文献 }
$$

1）野白喜久雄, 青木光夫 : 本誌, 52, 1014 (1957)

2) 同上 : 本誌, 52, 1011 (1957)

3）野白喜久雄, 中川清道 : 本誌, 52, 900 (1957)

3) 桜井芳人 : 栄養化学, 293 (1942)

5) The Association of Vitamin Chemist : Method of Vitamin Assay, 2 nd. edition, 205, 217 (1951)

6) 福井三郎, 坂本達雄, 谷 喜雄: ビタミン, 8, 218 (1955)

7) W.K. Calhoun : Ceral Chem., 35, 350 (1958)

8) G. W. BEADLE : J. Biol. Chem., 156, 683 (1944)

9）鈴木友二, 村岡三郎：ビタミン, アミノ酸の微生物定量法, 114 (1959)

10）小平了二：農化，32，49（1958）；33，626（1959）

11) 中村雄次, 伊藤雄太郎, 植村定治郎：酸工， 33，481（1955）

12）福井三郎, 谷 喜雄, 岸部忠信 : 酸工, 33, 1 (1955)

13）同上: 酸工, 33, 239 (1955)

14） 森太郎, 渡辺和夫, 高田小三郎: 醗工, 31, 421 (1953)

15） 森 太郎, 渡辺和夫：䤃工， 34，530 (1956)

16）猿野琳次郎：醴工，32，495（1954）

17）坂本政義, 飯田茂次：酸工，37，11 (1957) 